\section{Growth Regulators Do Not Increase Onion Bulb Size or Weight Under Greenhouse Conditions}

\author{
Vincent M. Russo ${ }^{1}$ \\ U.S. Department of Agriculture, Agricultural Research Service, South Central \\ Agricultural Research Laboratory, Lane, OK 74555
}

Additional index words. Allium cepa, abscisic acid, gibberellic acid, indole-acetic acid, jasmonic acid, kinetin, maleic acid hydrazide

\begin{abstract}
Exogenously applied plant growth regulators may affect development of onion, but little is know about how concentration or timing of application can affect bulb grade and quality. Two concentrations of the growth regulators abscisic acid, gibberellic acid, indole-acetic acid, jasmonic acid, kinetin, and maleic acid hydrazide, and water controls, were applied at the 7- and 20-leaf stages to the middle of the leaf whorl in greenhouse grown onion plants. Leaf and bulb weights were lighter, and bulb diameters were smaller, from plants treated with growth regulators applied at the 7-leaf stage than those from plants treated at the 20-leaf stage. Bulbs produced on plants treated with water were the same size, or larger, than those produced on plants treated with individual growth regulators.
\end{abstract}

Onion (Allium cepa L.) development is affected by photoperiod and temperature (Kato, 1996a, 1996b), and these stimuli effect processes at the cellular level. Investigations with onion has dealt with the states of rest, dormancy, and the breaking of dormancy since these have economic importance. However, since economic returns to the producer is also effected by marketability of bulbs, it is important to understand how factors affect bulb sizing.

Several classes of plant growth regulators affect physiological activities of the onion plant. Abscisic acid has been reported to induce senescence on onion plants and prolong bulb dormancy (Abdel-Rahman and Isenberg, 1974). Gibberellic acid has been proposed as the anti-bulbing hormone (Shibaoka, 1991) because it stabilizes microtubules in cells. If microtubules remain intact, cells do not increase in size and bulbs are not formed (Mita and Shibaoka, 1984). Indole-acetic acid and kinetin promoted leaf growth under laboratory conditions (Yoo et al., 1990). Kinetin also affects carbohydrate metabolism (Boothby and Wright, 1962), stimulates bulb growth (Karanov et al., 1992), and increases bulb marketability after 4.5 months in storage (Boyhan et al., 2001). It has been suggested that jasmonic acid that initiates bulb formation (Nojiri et al., 1992). Maleic acid hydrazide has been used for many years as an anti-sprouting agent when applied prior to harvest (Wittwer and Sharma, 1950; Isenberg and Ang, 1964).

There is minimal knowledge about how exogenous applications of growth regula-

Received for publication 11 Dec. 2001. Accepted for publication 13 Nov. 2002. Mention of a trademark, vendor, or proprietary product does not constitute a guarantee or warranty of the product by the U.S Dept. of Agriculture and does not imply its approval to the exclusion of other products that may also be suitable.

${ }^{1}$ Telephone: (580) 889-7395; Fax: (580) 889-5783; email: vrusso-usda@lane-ag.org. tors affect development and sizing of bulbs. Combinations of plant growth regulators have been marketed for use in onion production with the claim that the producer will benefit from increased grade and quality. These products are proprietary and concentrations of individual components or combinations of components are not readily available. It is not clear if these materials actually affect onion bulb development and sizing. Boyhan et al. (2001) used a $0.012 \%$ solution of a commercially available cytokinin and reported that there was no benefit to yield of onion. Since the use of these materials on onions is relatively new there is little information on what amounts of which growth regulators are needed, or when they should be applied, to affect developing onion plants. The objective of this study was to determine if concentration, and timing of application, of several growth regulators effected development of onion plants.

\section{Materials and Methods}

Plant cultivation and application of growth regulators. Four to six seeds of the yellow short-day onion, cv. TX1015 Y (Classic Seed, El Centro, Calif.), were sown in potting soil (Redi-earth; Scotts-Sierra, Marysville, Ohio) in 3.5-L pots in a glass greenhouse on 3 Oct. 2000. Plants were thinned to one perpot $\approx 2$ weeks after sowing. Plants were exposed to no more than $10 \mathrm{~h}$ of light from fluorescent bulbs (Son Agro, 430 lumens $/ \mathrm{m}^{2}$; Phillips, Sommerset, N.J.). Temperatures were set at $24^{\circ} \mathrm{C}$ day $/ 15$ ${ }^{\circ} \mathrm{C}$ night. Five-hundred milliliters of a soluble fertilizer (Peters Professional All Purpose Plant Food; United Industries, St. Louis) was applied at full strength $\left(2.65 \mathrm{~g} \cdot \mathrm{L}^{-1}\right)$ at 2-week intervals to each pot beginning 1 month after sowing. The fertilizer supplied $20 \%$ of N, $8.8 \%$ of P, and $16.6 \%$ of $\mathrm{K}$ per unit.

All growth regulators employed were obtained from Sigma (St. Louis). Most of the concentrations for the plant growth regulators employed exceeded those used by others (Abdel-Rahman and Isenberg, 1974; Karanov et al., 1992; Shibaoka, 1991; Wittwer and Sharma, 1950; Yoo et al., 1990). However, most of that work was at the plant culture, or excised tissue, level and the efficacy of each level of each plant growth regulator is not fully understood when employed at the plant level. Jasmonic acid has been extracted from tissue (Nojiri et al., 1992), and as best as can be determined has not been exogenously applied to developing plants in a greenhouse. The concentrations of jasmonic acid used were greater than those extracted from tissues. Five milliliters of either of two concentrations (1-fold and 2-fold) of 2-cis,4trans-abscisic acid (1 and $2 \mathrm{~mm}$ ), gibberellic acid (7.5 and $15 \mathrm{~mm}$ ), indole-3-acetic acid (60 and $120 \mathrm{~mm}),(-)-1 \alpha, 2 \beta-30 x 0-2$-[cis-2- pentenyl]-cyclopentaneacetic acid (jasmonic acid; 0.075 and $0.15 \mathrm{~mm}$ ), 6-Furfurylaminopurine (kinetin; 11.5 and $23 \mathrm{~mm}$ ), and 3,6-dihydroxypyridazine (maleic acid hydrazide; 0.5 and 1 M) were used. Controls were 5-mL of distilled water only. The plant growth regulators, or water, were applied using a large bore needle to deliver the compounds into the middle of the whorl of leaves so that they might better come in contact with meristematic areas. There were 252 pots in the experiment, and the single plant in each pot represented a replication. One hundred twenty-six plants were assigned to an application stage, when plants produced 7 or 20 leaves. Each plant growth regulator was applied to nine plants at each concentration (1- or 2-fold) for a total of 108 plants. Of the remaining 18 plants, 9 were treated with water at the 7- and 20-leaf stages, for a total of 126 plants used at each application stage. The experimental design was a split-plot with concentration being the main effect and time of application comprising the split.

Measurements. Bulb diameters were measured with calipers immediately after application of growth regulators or water at the 20-leaf stage. Measurement was at the widest point on the exposed bulb. Occasionally, it was necessary to gently remove the potting soil from around the bulb to ascertain the widest point. Plants were maintained in pots until tops broke over, and then harvested. Diameters of bulbs from plants treated at the 7- and 20-leaf stages were determined at harvest (25 Apr. 2001). If bulbs had developed a single split, the diameter was determined by measuring from the split to the outside of each bulb and the values were added. If bulbs developed multiple splits, two of the bulbs formed were chosen at random and the diameter determined as before. Leaves were separated from bulbs and fresh weights of both determined. Leaves, or the bulb, from each plant was placed in a forced air drying oven at $70{ }^{\circ} \mathrm{C}$ until dry weight stabilized. Data were analyzed with analysis of variance (ANOVA), and means separation was done by the Ryan-Einot-Gabriel-Welsch post-hoc test in SAS (ver. 7, SAS Inst., Cary, N.C.).

\section{Results and Discussion}

Plants treated with maleic acid hydrazide at the 7-leaf stage began bulb formation and 
then died about three weeks after treatment. These plants had average bulb fresh and dry weights, bulb diameters, and top fresh and dry weights of $17.7 \mathrm{~g}, 3.9 \mathrm{~g}, 17.7 \mathrm{~mm}, 32.7 \mathrm{~g}$, and $1.8 \mathrm{~g}$, respectively. Plants treated with malic acid hydrazide at the 20-leaf stage had average bulb fresh and dry weights, bulb diameters, and top fresh and dry weights of $244.4 \mathrm{~g}, 10.6 \mathrm{~g}$, $78.8 \mathrm{~mm}, 78.8 \mathrm{~g}$, and $8.6 \mathrm{~g}$, respectively. All bulbs treated with gibberellic acid at the 7-leaf stage exhibited splits at harvest. No other bulbs exhibited splits. Plant growth regulator, and application time, but not concentration of plant growth regulators affected bulb weights, final bulb diameter, and leaf weights (Table 1). There were no significant interactions. Plants treated at the 7-leaf stage were lighter and had bulbs with smaller diameters than did plants treated at the 20-leaf stage. Plants treated with maleic acid hydrazide were the lightest. Plants treated with gibberelic acid had bulbs with diameters similar to controls, jasmonic acid and abscisic acid. Plants treated with indole-acetic acid and kinetin had bulbs with diameters similar to controls, jasmonic acid, and abscisic acid. Plants treated with maleic acid hydrazide had bulbs with the smallest diameters. Bulb diameter increased $\approx 1.5 \mathrm{~cm}$ between treatment at the 20-leaf stage and harvest for all plants regardless of treatment, and no statistical differences were found.
Treatment with plant growth regulators did not increase bulb size in relation to controls. The significance reported for differences in bulb diameter due to growth regulators can be attributed to the smaller bulbs on plants treated at the 7-leaf stage with maleic acid hydrazide. For plants treated with gibberellic acid the combined diameters of the split bulbs likely contributed to their larger size, but rendered them unsuitable for the fresh market. Gibberellic acid stabilizes microtubule formation (Shibaoka, 1991), and thus bulb formation, and contributes to the formation of split bulbs when treatment occurs at the 7-leaf stage. Yoo et al. (1990) reported that indole-acetic acid and kinetin promoted leaf growth under laboratory conditions. The data indicate that there was no effect on leaf weights due to the growth regulators regardless of concentration.

Maleic acid hydrazide may affect the physiology of onions in ways other than to increase the dormancy period, which extends storage shelf-life (Isenberg and Ang, 1964; Wittmer and Sharma, 1950). Although the active site of maleic acid hydrazide is not well known, Nooden (1969) suggested that maleic acid hydrazide affected nucleic acid metabolism. Further research is needed to determine the site of action of maleic acid hydrazide, and how it affects the physiology of onions. It is difficult to transpose the re-

Table 1. Effects of application time, growth regulators and concentration on bulb fresh and dry weights, bulb diameter, and leaf fresh and dry weights at harvest.

\begin{tabular}{|c|c|c|c|c|c|c|}
\hline \multirow[b]{3}{*}{ Source } & \multirow[b]{3}{*}{ df } & \multicolumn{3}{|c|}{ Bulb } & & \\
\hline & & \multicolumn{2}{|c|}{$\mathrm{Wt}$} & \multirow{2}{*}{$\begin{array}{c}\text { Final diam } \\
(\mathrm{mm})\end{array}$} & \multicolumn{2}{|c|}{ Leaf wt } \\
\hline & & Fresh (g) & $\overline{\text { Dry }(g)}$ & & Fresh (g) & Dry $(g)$ \\
\hline Growth regulator $(\mathrm{G})$ & 6 & $* *$ & $*$ & $* *$ & $* *$ & $* *$ \\
\hline Application time (A) & 1 & $* *$ & $*$ & $* *$ & $*$ & $* *$ \\
\hline Concentration (C) & 1 & NS & NS & NS & NS & NS \\
\hline \multicolumn{7}{|l|}{ Application time } \\
\hline 7-leaf & & 167.3 & 9.9 & 67.6 & 117.6 & 7.4 \\
\hline 20-leaf & & $\begin{array}{c}223.8 \\
* *\end{array}$ & $\begin{array}{c}11.4 \\
*\end{array}$ & $\begin{array}{r}77.4 \\
\text { *** }\end{array}$ & $\begin{array}{c}127.6 \\
* *\end{array}$ & $\begin{array}{l}9.3 \\
* *\end{array}$ \\
\hline \multicolumn{7}{|l|}{ Growth regulator } \\
\hline Control (water) & & $233.6 \mathrm{a}^{\mathrm{z}}$ & $12.2 \mathrm{a}$ & $78.1 \mathrm{ab}$ & $123.9 \mathrm{a}$ & $8.2 \mathrm{a}$ \\
\hline Jasmonic acid & & $208.3 \mathrm{a}$ & $11.5 \mathrm{a}$ & $73.8 \mathrm{ab}$ & $134.6 \mathrm{a}$ & $9.1 \mathrm{a}$ \\
\hline Abscisic acid & & $206.0 \mathrm{a}$ & $10.8 \mathrm{a}$ & $74.7 \mathrm{ab}$ & $141.2 \mathrm{a}$ & $9.6 \mathrm{a}$ \\
\hline Indole-acetic acid & & $204.6 \mathrm{a}$ & $10.4 \mathrm{a}$ & $71.0 \mathrm{~b}$ & $128.4 \mathrm{a}$ & $8.7 \mathrm{a}$ \\
\hline Gibberellic acid & & $199.0 \mathrm{a}$ & $11.7 \mathrm{a}$ & $81.9 \mathrm{a}$ & $130.0 \mathrm{a}$ & $9.0 \mathrm{a}$ \\
\hline Kinetin & & $192.7 \mathrm{a}$ & $10.6 \mathrm{a}$ & $72.4 \mathrm{~b}$ & $132.1 \mathrm{a}$ & $8.7 \mathrm{a}$ \\
\hline Maleic acid hydrazide & & $124.4 \mathrm{~b}$ & $7.3 \mathrm{~b}$ & $55.7 \mathrm{c}$ & $68.2 \mathrm{~b}$ & $5.2 \mathrm{~b}$ \\
\hline
\end{tabular}

${ }^{z}$ Values in a column followed by the same letter are not significantly different, Ryan-Einot-GabrielWelsch post-hoc test.

Ns, **, *Nonsignificant or significant at $P<0.01$ or 0.05 , respectively, analysis of variance.

sults of a greenhouse trial to field conditions. However, these results indicate that these exogenously applied growth regulators did not increase bulb size.

\section{Literature Cited}

Abdel-Rahman, M. and F.M.R. Isenberg. 1974. The role of exogenous plant regulators in the dormancy of onion bulbs. J. Agr. Sci. 82: 113-116.

Boothby, D. and S.T.C. Wright. 1962. Effects of kinetin and other plant growth regulators on starch degradation. Nature 196:389-390.

Boyhan, G.E.,W.M. Randle,A.C. Purvis, P.M.Lewis, R.L. Torrance, D.E. Curry, and D.O.Linton. 2001. Evaluation of growth stimulants on short-day onions. HortTechnology 11:38-42.

Isenberg, F.M. and J-K. Ang. 1964. Effect of maleic hydrazide field sprays on storage quality of onion bulbs. Proc. Amer. Soc. Hort. Sci. 84:378-385.

Karanov, E., L. Iliev, G.T.S. Georgiev, M. Tsolova, V. Alexieva, and I. Puneva. 1992. Physiology and application of phenylurea cytokinins, $\mathrm{p}$. 842-851. In: C.M. Karsten, L.C. van Loon LC, and D. Vreughdenhil (eds.). Progress in plant growth regulation. Kluwer Academic Publ., The Netherlands.

Kato, T. 1996a. Physiological studies on the bulbing and dormancy of onion plants. VIII. Relations between dormancy and organic constituents of bulbs. J. Jpn. Soc. Hort. Sci. 35:142-151.

Kato, T. 1996b. Physiological studies on the bulbing and dormancy of onion plants. IX. Relation between dormancy of bulb and properties of its juice. J. Jpn. Soc. Hort. Sci. 35:295-303.

Mita,T. and H. Shibaoka. 1984. Gibberellin stabilizes microtubules in onion leaf sheath cells. Protoplasma 119:100-109.

Nojiri, H., H. Yamane, H. Seto, I. Yamaguchi, N. Murofushi, T. Yoshihara, and H. Shibaoka. 1992. Qualitative and quantitative analysis of endogenous jasmonic acid in bulbing and non-bulbing onion plants. Plant Cell Physiol. 33:1225-1231.

Nooden, L.D. 1969. The mode of action of maleic hydrazide: inhibition of growth. Physiol Plant. 22:260-270.

Shibaoka, H. 1991. The role of gibberellin in the formation of bulbs, p. 220-228. In: N. Takahashi, B.O. Phinney, and J. MacMillan (eds.). Giberellins. Springer-Verlag, Berlin, Heidelberg, New York.

Wittwer, S.H. and R.C. Sharma. 1950. The control of storage sprouting in onions by preharvest foliage sprays of maleic hydrazide. Science 112:597-598.

Yoo, K.S., L.M. Pike, and B.G. Cobb. 1990. Promotion of in vitro leaf growth on inner scales excised from dormant onion bulbs. HortScience 25:228-229. 